\title{
The Effect of Sexual Violence on Children
}

\author{
Dini Rakhmawati* \\ University of PGRI Semarang \\ Semarang, Indonesia \\ dini.upgris@gmail.com* \\ Desi Maulia \\ University of PGRI Semarang \\ Semarang, Indonesia \\ desimaulia@upgris.ac.id
}

\author{
Chr. Argo Widiharto \\ University of PGRI Semarang \\ Semarang, Indonesia \\ argowidiharto@upgris.ac.id
}

\author{
Suwarno Widodo \\ University of PGRI \\ Semarang, Indonesia
}

\begin{abstract}
Sexual crime in children increases significantly every year. In 2015 there were around 757 cases of sexual violence against children and women. The phenomenon of sexual violence against child victims must be given more attention because it can injure the victims because of traumatic events which were brought to adulthood. The introduction of the impact of sexual violence on children is expected to map problems that occur in children, so that parties who are competent in their fields can take steps to prevent, intervene and regulate comprehensively. This study uses a qualitative case study approach with the participation from child victims of sexual violence. The level of trust in the data used significant others, among others, playmates, village staff who handle cases, and health analysis forums. Data analysis used is descriptive analysis of case studies. The results of the study show that the victim is psychologically experiencing inferiority, nonassertiveness and anxiety. This experience will make the victim easier to experience sexual violence. Parental understanding of the problem of sexual violence also strengthens the slow resolution of problems, but this can be eliminated by the concern of local governments such as districts (kelurahan) and sub-districts (kecamatan) that immediately seek solutions to the problem. Thus, parental factor does not become an obstacle to the problem if the presence of the local government plays an active role in solving the problem.
\end{abstract}

Keyword-sexual violence, child, impact

\section{INTRODUCTION}

In Indonesia, the act regarding children protection is regulated in Act No. 23 of 2003. Childhood is a period where children should get happiness in their life. If children's growth and development (physical and psychological) is hampered, they will find trouble regarding their growth [1]. One of problems faced by children in Indonesia nowadays is sexual violence.

Crime against children raises every year. Sexual violence case shows the increase of the number of victims of pre-teenage ages (from kindergarten age until the beginning of teenage). On the other hand, most of the perpetrators are also teenagers who know the victims. Semarang City is categorized as 'red zone' of violence against women and children [2].
According to the data obtained from DP3A, it was found that as of 31 December 2018, there were 156 violence cases in Semarang City. The victims where 22 men and 131 women. Based on the type of violence, these cases consisted of 60 physical violence cases, 68 psychological violence cases, 21 displacement cases, 25 sexual violence case and 3 other cases. Meanwhile, based on the victims' age, there were 12 victims of age $0-5,27$ victims of age 6-12, 20 victims of age 13-18 and 78 victims of age above 19 .

More specifically, WHO stated that at least 1 of 3 women in the world has ever experienced physical or sexual violence. Statistic from the National Committee of Anti Violence on Women in 2015, shows that female children and adult women are not safer at their own home because most perpetrators are their close relatives or people who are close to their family. Sexual violence that they experienced during childhood will cause wound. This wound will remain on them until adulthood [3].

The effect of sexual violence on children is very pitiful. The victims will suffer serious psychological disorder. The example of psychological disorders caused by sexual violence or trauma are hard to trust others, be afraid or worry about having sexual relations, depression, suicidal thought, self-harming, low self-esteem, lack of confident, feeling guilty, anger, being alone, reluctant to get along with others and eating disorder. Sexual violence during childhood also has long-term effects such as mental health problem in adulthood, relationship problem with parents and problem regarding children adjustment on the next generation [4].

The result of Rakhmawati's 2016 research shows that psychological effect of sexual violence (incest) on teenager causes teenage girl to feel inferior, hate men (the perpetrators), feel anxious and insecure at home, long-term trauma, physical wound such as bruise or bleeding, depression, suicide and anxiety. Considering the condition of sexual crime on children, since 2015, the Indonesian Committee of Children Protection (KPAI) has declared that Indonesia is in sexual crime emergency condition. This declaration was followed by the issue of Presidential Instruction No. 5 of 2014 about National Movement against sexual violence on children. The first parameter of this emergency condition is the high number of sexual violence case. The second parameter is the perpetrators, who are the 
people who should protect children such as parents, teachers, social environment etc [5].

Like what just happened in the village of Pongagan. Recently, there was a sexual violence against children. According to the interview conducted on 1 June 2018 with the head of the Village Health Forum, it was found that there were three children sexual violence cases with three perpetrators who were also categorized as children. The victims were bound and gagged one by one. Their genital area was then rubbed with soap and glue. The youngest child was 5 years old (PAUD) and she suffered severe trauma, physical and festering injuries. The parents seemed to have objected because this case was reported to the village. From this case, it needs deeper study to understand the effects of sexual violence on children to gain the image of dynamics on how children play role and live their daily life.

This research used qualitative approach of case study. Case study is aimed to understand significant activity/process which takes place in a case and to appreciate the uniqueness and complexity of the case [6]. In this research, the case study which was used was instrumental case study. Instrumental case study is aimed to understand a thing in general through study on certain case $[6,7]$.

The participants of this research were student who had experienced one of children sexual violence forms, kelurahan staffs, kelurahan's health forum and peer group. The main participant of this research was student as victim of children sexual violence since we can dive their psychological dynamics

This research used interview guide as research instrument. The interview guide was arranged based on the forms of sexual violence and psychosocial theory from Miller which says that psychosocial on human consists of psychological (P), social (S) and environment (E). The data of this research was obtained through deep interview with the participant and the significant others [8]. The interview which was used was semi-structured interview with interview guide which can be developed on field.

\section{RESULT AND DISCUSSION}

\section{Psychosocial Aspect}

Based on psychological aspect, the participant will experience anxiety and trauma related to the event that have happened. The participant also had low self-esteem. The anxiety of the participant can be seen on the statement of the participant's mother as follows: "He only plays near house and mingles with people that he already knows. He used to play far from home and run around. Now he needs his cousin to accompany him playing; if there is no his cousin, he is afraid, only playing at home."

The sexual violence experienced by the participant is also a traumatic event for the participant although it is not a severe trauma, because the participants do not need to withdraw from the community. He only limits himself to interact with others. Psychologically, the participant is categorized as a child who has low self-esteem although this low self-esteem is not the effect of sexual violence experienced by the participant. This low self-esteem is likely as one of the causes of someone becoming a victim of sexual violence.

The participants also need social support from peer groups, family and teacher at school. This indicator can be seen from the participant's statement when he was asked where he played. He answered, "in front of house with friends, playing together not far, with similar friend (peer group)". For recovery, the participant actually needed appropriate social support both from parents and related parties such as teacher at school, social worker or peer group. In this case, social support from parents is less optimal because most of participants come from poor family.

On the other hand, the support from father as the head of the is not strong although father is the right figure as a mode for male participant. For the participant, his father has less role on him. It is shown when he drew a family picture. The participant rarely draw his father.

Environmental aspect in this child sexual violence case did not give significant influence on the participant because the participant easily avoided his environment. In addition, the environmental aspect was localized only at the place where the sexual violence happened. The participant succeeded in implementing coping by avoiding the environment where the incident took place.

\section{Self-Acceptance}

Based on the result of children graphic analysis, it was found that the victim felt that he is small figure, powerless and needs protection from adults around him especially his mother. He feels calm when he is with his mother because he thought that his mother will take care of him. In addition to mother, the other figure who makes him feeling calm is mak'e (grandmother). $\mathrm{R}$ needs to be close with his father but he feels that his father is out of his reach when he needs help. Regarding affection, he is sensitive child and actually he is cheerful. He just has anxiety that he hides and it makes him less brave to show his strength. In social skill domain, he has interest to interact with outer world. However, he often feels anxious so that he prefers to behave passively and wait for invitation. He also needs to make sure that his surrounding is safe.

Self-acceptance is individual ability to accept themselves as it is and to admit their existence objectively. In $\mathrm{R}$ case, since the incident until now, $\mathrm{R}$ is still full of fear and anxiety [9]. He cannot accept that this tragedy happened to his life yet. The person who accepts herself/himself has characteristics as follows: a. Having belief in their ability to face life; b. Considering themselves precious as human who is equal to others; c. Dare to bear responsibility regarding their behavior; d. Accepting praise and reproach objectively; e. Did not blame themselves for their weakness nor deny their strength [10].

Based on the data analysis, it can be concluded that the child has not obtained good self-acceptance after the sexual violence. The incident which happened to him was interpreted as a naughty action from other which hurt him and made him hesitate to tell a lot. There is strong desire to 
avoid talking about the case. He also does not have faith that he can face his difficulties alone.

\section{The Dynamics of Child's Behavior After Sexual Violence}

The behavioral changes that appear after $\mathrm{R}$ experienced the sexual violence related to a sense of security when the child must be in a new situation or is hanging out in his environment. He felt anxious and insecure. He felt that he needs the protection of his closest adults. There was strong insecurity in him and it pushed him to be introverted and limit his social relationship. He avoided to start conversation and interact with new people. He also avoided conflict. He will play with friends if he is accompanied by his mother or the playground is close to his house.

The condition of the child is as weak victim and the youngest child, so $\mathrm{R}$ thinks that he is really powerless. As a result, he has low self-efficacy to interact with his friends who have the same age. This low self-efficacy makes him afraid to be in his own situation without someone protecting him.

Academically, there is no change in behavior or learning achievement after a child experiences sexual violence. One of the reasons is because the incident happened when $\mathrm{R}$ was in kindergarten age which did not demand $\mathrm{R}$ to study formally. In addition, in R's age which was categorized as the phase of perseverance vs sense of low self-esteem (according to psychosocial theory from Erick Erikson), it was found that the level of R's desire to be persevere and be competent was developing.

\section{Discussion}

This case study research used psychosocial approach. Psychosocial in human consists of psychological (P), social (S) and environmental (E). Psychological (P) refers to power and resources in individual such as ideas, belief and values that the individual creates. Social $(S)$ is a social relationship, both relation inside a society and the relation between societies. Environmental (E) is the relation between individual and power and resources from outside nature or physical environment of the individual. Human lives in three bonds: psychological, social and environmental. These three things are bound in psychosocial ecology term [8].

The psychological aspect on sexual violence which occurred on the participant deals with anxiety, low selfesteem (inferiority) and trauma although in mild scale. Faith is perception about certainty of feeling is someone's mind or perception which is arranged in exact behavior. Furthermore, faith is perception which involves feeling of being able to do something well based on impression of one's self or from the relation with impression or memory which awakes feeling [11]

Inferiority in the participant is the faith and values that he created based on his experience with the environment. This sense of inferiority was strengthened by the participant's self-perception. The participant has made perception that he will make mistake and will be scolded by friends or others.
This situation is pursuant to the opinion of Hume that participant believes something (making mistake and being scolded) and it involves the participant's feeling. Participant's inferiority caused participant's anxiety in facing problem and it influenced participant's behavior in daily life. Participant was believed to be weak, coward and not assertive and therefore he easily became the target of peer violence. The victim of violence is a party who does not have ability to fight the violence that he/she experiences because the victim has less power compared to the perpetrator. For example, the victim may have smaller or weaker body, weaker social status, or less in number. The participant's condition is pursuant to the theory of Craig, Pepler \& Blais since his body is small, he is not assertive and his family's social economy status is also weak [12]. Individual's faith and values relate to socialcultural environment. Human's mind concerning faith is generally the representation of social or cultural information [13]. Human's faith is obtained through related mechanism by studying cognitive content of others. Children who live in environment with irrational belief will tend to have many irrationals believe. On the contrary, children who live in environment with rational belief will tend to have rational belief.

Concerning social aspect, the participant needed social support from his surrounding, such as parents, sister or peer group. Social ecology relates to social relation including the relation in a society and between societies. Individual social relationship in society will spark social support. Social support, according to Wilcox \& Vernberg [14], is a system from social continuity which enables individual to get suggestion regarding themselves and individual's hope towards others. This social support is an interpersonal transaction which involves emotion (love, empathy), instrumental help (goods or service), information about environment and evaluation (information relevant to selfevaluation). Thoits says that social support will be effective if it comes from emotional support from the right person [15].

\section{CONCLUSION}

The case of sexual violence on children is a case which can be treated with psychosocial approach. Through psychosocial understanding of sexual violence victims, the treatment of this case will be more focused and effective. In this case, the most significant factors which support the resolution of the case is an understanding of the psychological aspect of the victim and providing the correct social support. The result of this research showed that the victim psychologically experienced inferiority, nonassertiveness and anxiety. These feelings will make the victim easier to be the target of sexual violence behavior. The parents' understanding concerning the problem of sexual violence also slowed down the resolution of this case. However, it can be eliminated if the local government such as district and sub-district can immediately find solutions for this case. Therefore, parents are not an obstacle of resolution of this case if the local government actively plays role in solving the problem. 


\section{REFERENCES}

[1] Hurlock, E. 2002. Psikologi Perkembangan. Jakarta: Erlangga.

[2] Faisol, E. (2016) Jateng Zona Merah Kekerasan Perempuan dan Anak. https://m.tempo.co/read/news/Diakses 20 Mei 2016.

[3] Iskandar, Livia. 2016. Pengalaman Kekerasan Seksual di Masa Kanak: Upaya Sintas dan Institusi Pemulihan. Jurnal Perempuan, Vol. 21 No 2, Mei 2016, hlmn. $121-127$.

[4] Roberts, R., O'Connor, T., Dunn, J., Golding, J., \& Team, A. S. (2004). The effects of child sexual abuse in later family life; mental health, parenting and adjustment of offspring. Child Abuse \& Neglect, 28(5), 525-545. doi:10.1016/j.chiabu.2003.07.006. Retrieved From http://eresources.perpusnas.go.id.

[5] Rakhmawati, Ellya. 2016. Dampak Psikologis Kekerasan Seksual Pada Remaja. Semarang: Universitas Soegijapranata Semarang. Unpublished Undergraduate Thesis.

[6] Stake, 1995. The Art Of Case Study Reseach. Thousand Oaks,CA: Sage.

[7] Creswell, J W. (2015). Penelitian Kualitatif dan Desain Riset: Memilih Di Antara Lima Pendekatan. (diterjemahkan oleh Ahmad Lintang Lazuardi). Yogyakarta: Pustaka Pelajar.

[8] Miller, A. (1999). Environmental Problem Solving. Psychosocial Barriers to Adaptive Change. New York: Springer-Verlag.
[9] Handayani, M.M. 2000. Efektivitas Pelatihan Pengenalan Diri Terhadap Peningkatan Penerimaan Diri dan Harga Diri pada Remaja. INSAN, Vol.2, No.1,39-46.

[10]Wrastari 2003. Pengaruh Pemberian pelatihan Neuro Lingusitik Programming (NLP) terhadap Peningkatan Penerimaan Diri Penyandang Cacat Tubuh pada Remaja Penyandang Cacat Tubuh di Pusat Rehabilitasi Panti Sosial Bina Daksa "Suryatama" Bangil Pasuruan. Skripsi Sarjana Tidak Diterbitkan.

[11] Gorman, M. M., Studies, H., Xix, V., April, N., \& Gorman, M. M. (1993). Hume's Theory of Belief, XIX(1), 89-102.

[12] Craig, W., Pepler, D., \& Blais, J. (2007). Responding to bullying: What works? School Psychology International, 28(4), 465-477. https://doi.org/10.1177/0143034307084136.

[13]Donoghue, C., Almeida, A., Brandwein, D., Rocha, G., \& Callahan, I. (2014). Coping with verbal and social bullying in middle school. The International Journal of Emotional Education, 6(2), 40-53. Retrieved from http://search.ebscohost.com/login.aspx?

[14] Sarason, B. R., Sarason, I. G., Hacker, T. A., \& Basham, R. B. (1985). Concomitants of social support: Social skills, physical attractiveness, and gender.

[15] Iskandar, Livia. 2016. Pengalaman Kekerasan Seksual di Masa Kanak: Upaya Sintas dan Institusi Pemulihan. Jurnal Perempuan, Vol. 21 No 2, Mei 2016, hlmn. 121 - 127. 